\title{
Ethnologies
}

\section{Stagolee Shot Billy. By Cecil Brown. (Cambridge: Harvard University Press, 2004. Pp. viii +296, acknowledgments, introduction, notes, bibliography, index, ISBN 0-674-01626-2)}

\section{Jack Beck}

Volume 28, numéro 1, 2006

Haïti - Face au passé

Haïti - Confronting the Past

URI : https://id.erudit.org/iderudit/014162ar

DOI : https://doi.org/10.7202/014162ar

Aller au sommaire du numéro

\section{Éditeur(s)}

Association Canadienne d'Ethnologie et de Folklore

ISSN

1481-5974 (imprimé)

1708-0401 (numérique)

Découvrir la revue

Citer ce compte rendu

Beck, J. (2006). Compte rendu de [Stagolee Shot Billy. By Cecil Brown.

(Cambridge: Harvard University Press, 2004. Pp. viii +296, acknowledgments, introduction, notes, bibliography, index, ISBN 0-674-01626-2)]. Ethnologies,

28(1), 296-297. https://doi.org/10.7202/014162ar d'utilisation que vous pouvez consulter en ligne.

https://apropos.erudit.org/fr/usagers/politique-dutilisation/ 
Stagolee Shot Billy. By Cecil Brown. (Cambridge: Harvard University Press, 2004. Pp. viii +296, acknowledgments, introduction, notes, bibliography, index, ISBN 0-674-01626-2)

The first book I reviewed for Culture and Tradition was The Bonnie Earl of Murray by Edward D. Ives. There is an uncanny parallel between it and Stagolee Shot Billy. Both books set out to examine a traditional ballad and its background, and both authors go about their task in similar ways, displaying a combination of rigorous scholarship and love of their subject. In Ives' case the ballad was Scottish, while Brown examines a quintessential black American example.

Brown's introduction contextualizes existing popular knowledge of the historical events and resulting ballad. The book then divides into three sections: "Stagolee and Saint Louis," "The Thousand Faces of Stagolee" and "Mammy-Made: Stagolee and American Identity." The first section examines the circumstances of the events that gave rise to the ballad and the characters who played significant roles, while the second looks at the various oral forms of the Stagolee story: recitations, ballads and hollers. Finally, in the third section, Brown moves into the significance of the story for modern American culture.

Brown says towards the end of his introduction that "In the following chapters there is a lot of repetition" (17), then makes the point that "in the oral tradition repetition is the essence of communication" (18). Finally he says "even when several performers use the same motif the sequence of events and the kind of figure created through the narrative remain essentially the same" (18). I wonder if this explanation of an oral illiterate communication device within a work of literature is entirely convincing. The repetition does seem a little heavy going at times, although I am willing to acknowledge that that may simply say something about my attention span!

The amount of research evident in the book is very impressive. The events surrounding Billy Lyons' murder in Saint Louis are assembled into a colourful description of the city's red light districts at the time. The existing folklore studies and archival materials referenced, ranging from Greil Marcus to Karl Marx and from Bob Dylan to James Baldwin, are skillfully used by Brown to support his own arguments.

Almost anyone with an interest in folksong will be familiar with the Stagolee ballad, whether by that name or the many variations of it. Most people will have a notion that it describes historical events. However, a variety of opinions exist as to where and when the events 
took place. Brown's book begins by constructing a convincing picture of the likely crime scene, but then uses this as the launch point for a much broader study of the Stagolee figure as folk hero. It is interesting to note that some of the ballad texts are extremely accurate regarding the details of both the crime and the subsequent trial.

The book places the Stagolee ballad firmly within a continuum, preceded by African oral narrative forms and archetypes, coexisting with the emerging blues and shack bully hollers, feeding into the white cowboy and railroad song traditions, and finally becoming a political icon for the black consciousness movement. As a singer of traditional ballads, I found this perhaps the most fascinating section of the book. It shows how the original Stagolee (Lee Shelton) is transformed from a flashy character living on his wits in ragtime Saint Louis to a folk hero for a whole culture.

It is in the final section that the book aspires to more than a standard examination of a piece of folklore. Brown strives to show that Stagolee has become an archetypal cultural and political template, underlying not only much black writing of the late twentieth century, but also reflecting the experiences of downtrodden people everywhere. Here Brown examines the contribution of Stagolee to modern American literature, such as Tennessee Williams and James Baldwin, then goes on to look at his role within political radicalism, as related to Eldridge Cleaver and Bobby Seal. He ends by suggesting that in rap music and hip-hop we have the latest embodiment of Stagolee in oral tradition.

This book will be of great interest to anyone studying the oral traditions of black America - it is both scholarly and thorough. However, more than that, it is a thoroughly good read to boot!

Jack Beck

White Springs

Florida

\section{Reference}

Ives, Edward D. 1997. The Bonny Earl of Murray: The Man, The Murder, The Ballad. East Linton: Tuckwell Press. 